\title{
Peningkatan Minat Keterampilan Membaca Melalui Media Power Point Interaktif Siswa Kelas II SDN Jabon 1 Kecamatan Banyakan Kabupaten Kediri Tahun Ajaran 2019 / 2020
}

\section{Diterima: \\ 5 Juni 2021 \\ Revisi:}

29 Juli 2021

Terbit:

1 Februari 2022

\author{
Reni Nurmalasari \\ SDN Jabon 1 Kediri \\ Kediri, Indonesia \\ E-mail: reninurmalasari90@gmail.com
}

\begin{abstract}
Abstrak - Penelitian ini dilatarbelakangi oleh harapan pelaksanaan proses belajar mengajar mata pelajaran Bahasa Indonesia khususnya pada Peningkatkan minat keterampilan membaca melalui media Power Point Interaktif dapat terlaksana tuntas sesuai dengan Kriteria Ketuntasan Minimal (KKM) yang ditetapkan. Tujuan dari penelitian ini yakni untuk mendapatkan gambaran obyektif tentang peningkatan hasil belajar Bahasa Indonesia materi Peningkatkan minat keterampilan membaca melalui media Power Point Interaktif pada siswa kelas II semester 1 SDN Jabon 1 Kecamatan Banyakan Kabupaten Kediri. Adapun tujuan dari penelitian Tindakan Kelas ini adalah untuk meningkatkan minat keterampilan membaca melalui media Power Point Interaktif pada siswa kelas II semester 1 SDN Jabon 1 Kecamatan Banyakan Kabupaten Kediri. Dari analisis data didapatkan bahwa motivasi belajar siswa meningkat dari pra siklus hingga siklus ke II. Prestasi belajar siswa juga meningkat dari pra siklus, siklus I hingga siklus II secara bertahap. Kesimpulan penelitian ini mengungkapkan bahwa penggunaan media power point interaktif dapat meningkatkan proses pembelajaran membaca. Hal ini ditunjukkan dengan adanya peningkatan keaktifan siswa dalam merespon guru saat melakukan tanya jawab tentang isi cerita yaitu sebesar 50\% dan peningkatan dalam menyimpulkan isi cerita yang dibacanya yaitu sebesar $41,67 \%$. Lebih lanjut, hal ini menyebabkan kemampuan membaca nyaring siswa meningkat. Peningkatan kemampuan membaca nyaring melalui media PPT Interaktif pada siklus I sebesar 5,06, kondisi awal 63 meningkat menjadi 68,06. Pada siklus II meningkat sebesar 12,59, kondisi awal 63 meningkat menjadi 75,59 .
\end{abstract}

Kata Kunci- hasil belajar, keterampilan membaca, media power point interaktif

Abstract - This research is motivated by the hope that the implementation of the teaching and learning process for Indonesian subjects, especially in increasing interest in reading skills through Interactive Power Point media can be carried out completely in accordance with the specified Minimum Completeness Criteria (KKM). The purpose of this study is to obtain an objective picture of improving Indonesian language learning outcomes. reading skills through Interactive Power Point media in second semester students of SDN Jabon 1, Banyakan District, Kediri Regency. The purpose of this Classroom Action research is to increase interest in reading skills through Interactive Power Point media in class II semester 1 students at SDN Jabon 1, Banyakan District, Kediri Regency. From the data analysis, it was found that students' learning motivation increased from the pre-cycle to the second cycle. Student achievement also increased from pre-cycle, cycle I to cycle II gradually. The conclusion of this study reveals that the use of interactive power point media can improve the process of learning to read. This is indicated by an increase in student activity in responding to the teacher when asking questions about the content of the story, which is $50 \%$ and an increase in concluding the content of the story he reads, which is $41.67 \%$. Furthermore, this causes the students' reading aloud ability to increase. The increase in the ability to read aloud through Interactive PPT media in the first cycle was 5.06, the initial condition of 63 increased to 68.06. In the second cycle it increased by 12.59, the initial condition of 63 increased to 75.59 .

Keywords - learning outcomes, reading skills, interactive power point media 


\section{PENDAHULUAN}

Minat membaca anak adalah suatu perhatian yang kuat dan mendalam disertai dengan perasaan senang terhadap kegiatan membaca sehingga mengarahkan anak untuk membaca dengan kemauanya sendiri. Aspek minat membaca meliputi kesenangan membaca, kesadaran akan manfaat membaca, frekuensi membaca dan jumlah buku bacaan yang pernah dibaca oleh anak (Mustakim 1994).

Minat merupakan motivator yang kuat untuk melakukan aktivitas, aktivitas membaca akan dilakukan oleh anak atau tidak sangat ditentukan oleh minat anak terhadap aktivitas tersebut. Akan tetapi dalam kegiatan keseharian, siswa lebih senang bermain dan jarang beraktifitas membaca baik buku bacaan maupun buku pelajaran. (Nurgiyantoro 2010). Untuk menumbuhkan minat membaca pada anak didik peranan guru sangat penting dalam merubah kondisi yang terjadi, sehingga perlu diadakan solusi dan inovasi untuk isu tersebut. Selain itu juga diperlukan kreatifitas guru dalam menggunakan media yang dapat membantu siswa dalam pembelajaran .

Penggunaan media pembelajaran harus disesuaikan dengan tahap perkembangan anak (Dewi 2017). Terlebih lagi untuk anak kelas bawah khususnya kelas II, pada usia ini anak-anak masih menginginkan bermain, dan tentunya memerlukan sesuatu yang menyenangkan dalam proses pembelajaran (Qudsyi 2010). Terutama dalam situasi dan kondisi disaat wabah covid 19 melanda negara tercinta Indonesia, dan mengharuskan anak -anak belajar dari rumah dan pembelajaran sebagian besar harus dilakukan melalui media daring.

Berbagai macam media pembelajaran yang digunakan oleh guru, termasuk media power point interaktif. Media power point adalah program aplikasi yang dirancang untuk menampilkan program multimedia. Diyakini bahwa penggunaan multimedia dalam suatu kegiatan belajar mampu meningkatkan hasil kegiatan belajar. Microsoft Power Point menggabungkan berbagai jenis media ke dalam suatu paket presentasi yang menarik, yang akan menarik perhatian dan bisa meningkatkan motivasi belajar anak (Mulyanta and Marlon Leong 2009). Berdasarkan permasalahan diatas maka penulis mengambil judul Peningkatan Minat Keterampilan Membaca Melalui Media Power Point Interaktif Siswa Kelas II SD Negeri Jabon 1 Banyakan Kabupaten Kediri. 
PTK, Vol.2 No.2 2022

ISSN: 2747-1977 (Print) / 2747-1969 (Online)

DOI: https://doi.org/10.53624/ptk.v2i2.51

\section{METODE}

Jenis penelitian yang digunakan adalah penelitian tindakan kelas (PTK), dengan tahapan yaitu 1) perencanaan, 2) pelaksanaan, 3) pengamatan, 4) refleksi. Konsep penelitian ini mengacu pada model PTK Kemmis dan MC. Taggart (Iskandar 2009). Dalam penelitian ini peneliti sebagai instrumen utama mengandung arti, yaitu sebagai pengumpul dan pengolah data (Aqib 2009). Peneliti sebagai perencana tindakan maksudnya adalah peneliti yang membuat rancangan pembelajaran selama berlangsungnya penelitian. Kemudian peneliti melaksanakan pembelajaran di kelas sebagai guru kelas 2 SDN Jabon 1 Kecamatan Banyakan Kabupaten Kediri.

Subjek yang diteliti pada penelitian ini adalah siswa kelas 2 pada semester genap tahun ajaran 2019/2020 di SDN Jabon 1 Kecamatan Banyakan Kabupaten Kediri dengan jumlah siswa sebanyak 20 siswa, yang terdiri dari 10 siswa laki-laki dan 10 siswa perempuan. Waktu penelitian ini dilaksanakan mulai tanggal 20 Januari 2020 sampai tanggal 20 Februari 2020 semester genap tahun pelajaran 2019/2020.

\section{HASIL DAN PEMBAHASAN}

A. Hasil Penelitian

1. Analisis Data Pra Siklus (Siklus I)

Data yang diperoleh dalam penelitian ini berupa data kuantitatif yaitu tes unjuk kerja membaca nyaring yang diberikan pada siswa di setiap siklus dan data kualitatif yaitu lembar observasi penggunaan media PPT Interaktif kemudian dianalisis.

Analisis Data Kuantitatif

Hasil tes yang diperoleh dari siswa dianalisis untuk mengetahui seberapa besar peningkatan kemampuan membaca nyaring dengan menggunakan media PPT Interaktif. Analisis ini dilakukan dengan menghitung jumlah siswa yang memenuhi Kriteria Ketuntasan Minimal (KKM) serta menghitung nilai rerata kelas. Jika minimal 75\% dari siswa telah mencapai Kriteria Ketuntasan Minimal (KKM) yakni sebesar 65 dan rerata nilai kelas minimal 65 sesuai dengan kriteria keberhasilan dalam penelitian ini, maka dapat diasumsikan bahwa penggunaan media PPT Interaktif dapat meningkatkan kemampuan membaca nyaring siswa.

2. Analisis Data Siklus I

a. Data hasil pengamatan

Dalam siklus I ini yang dilakukan oleh peneliti, saat pembelajaran membaca nyaring menggunakan media PPT Interaktif berlangsung. Secara umum, pelaksanaan pembelajaran 
oleh guru sudah sesuai dengan skenario pembelajaran dalam Rencana Pelaksanaan Pembelajaran (RPP).

b. Refleksi

Pada tahap ini peneliti menganalisis dan mengolah nilai yang terdapat pada lembar observasi siswa dan guru. Berdasarkan pengamatan dari lembar observasi siswa dan guru dapat ditemukan kelemahan-kelemahan sebagai berikut:

1) Kegiatan guru dalam pembelajaran sulit menyesuaikan dengan RPP yang dirancang sebelumnya.

2) Guru kurang mampu memotivasi siswa ketika pembelajaran.

3) Guru kurang mampu mengkondisikan siswa untuk membentuk kelompok.

4) Guru kurang cakap dalam menyampaikan materi.

\section{Analisis Data Siklus II}

Setelah dilaksanakan analisis siklus I, dapat dilihat beberapa temuan baik berasal dari siswa maupun dari guru. Pertama, proses pembelajaran membaca nyaring menggunakan media power point interaktif semakin meningkat. Hal ini ditunjukkan dengan adanya peningkatan siswa dalam melaksanakan dan merespon perintah guru, menyimak guru saat membacakan cerita, melihat gambar dan membaca teks narasinya secara klasikal setelah dibacakan oleh guru, memberikan tanggapan atau komentar terhadap gambar, tokoh, atau yang lainnya, menyimak temannya yang sedang mendapatkan giliran membaca, merespon guru saat melakukan tanya jawab tentang isi cerita, dan menyimpulkan isi cerita yang dibacanya. Walaupun demikian, masih ada juga beberapa siswa yang masih belum begitu memperhatikan jika ada temannya yang sedang membaca di depan kelas. Siswa lebih cenderung asyik bercakap-cakap dengan temannya. Hal ini secara tidak langsung yang membuat siswa belum bisa membaca nyaring dengan baik. Hal ini dikarenakan pada saat ada siswa yang membaca di depan kelas, jika terdapat kesalahan-kesalahan dalam membaca maka guru mengoreksi dan membenarkannya. Jika siswa lain tidak memperhatikan temannya yang sedang membaca di depan, maka siswa tersebut tidak mengetahui letak-letak kesalahan dalam membaca nyaring.

Kedua, guru kurang membimbing dan membenarkan jika ada siswa yang mengalami kesalahan dalam membaca nyaring. Guru kurang optimal dalam membimbing siswa-siswanya. Hal ini terlihat pada saat siswa membaca secara bergiliran di depan kelas. Terkadang guru tidak mengoreksi kesalahan-kesalahan siswa dalam membaca.

Ketiga, kemampuan membaca nyaring siswa semakin meningkat. Hal ini ditunjukkan dengan adanya peningkatan nilai membaca nyaring setelah diberikan tindakan menggunakan media PPT Interaktif. Namun demikian, masih banyak siswa yang membaca tidak begitu memperhatikan aspek-aspek membaca nyaring (ketepatan, lafal, intonasi, kelancaran, 
PTK, Vol.2 No.2 2022

ISSN: 2747-1977 (Print) / 2747-1969 (Online)

DOI: https://doi.org/10.53624/ptk.v2i2.51

kenyaringan) atau dengan kata lain masih terdapat kesalahan dalam membaca. Semua siswa masih menunjukkan kekurangan pada setiap aspek membaca nyaring. Dari hasil observasi terhadap siswa pada saat membaca dapat ditemukan bahwa masih ada beberapa siswa yang mengalami kesulitan. Kesulitan-kesulitan tersebut antara lain: a) ada beberapa siswa yang kurang lancar dalam membaca kata, b) ada beberapa siswa yang ketika membaca kalimat, berhenti di tengah-tengah kalimat, c) ada beberapa siswa yang ketika membaca kata, akhiran dari kata dasar tersebut dihilangkan atau tidak dibaca, d) ada beberapa siswa yang ketika membaca ada tanda baca titik (.), tidak berhenti tetapi langsung membaca kata selanjutnya tanpa ada jeda, e) ada beberapa siswa yang salah dalam mengucapkan kata, f) ada beberapa siswa yang menambahkan kata-kata tertentu yang tidak ada dalam teks bacaan, g) ada beberapa siswa yang menghilangkan atau tidak membaca kata-kata tertentu dalam teks bacaan, h) ada beberapa siswa yang membaca dengan intonasi yang tidak tepat atau dengan kata lain tidak memperhatikan tanda baca, dan i) ada beberapa siswa yang kurang nyaring dalam membaca.

Dengan menggunakan media PPT Interaktif, dapat dilihat bahwa nilai rerata kemampuan membaca nyaring siswa kelas II SDN Jabon 1 pada tindakan siklus II mengalami peningkatan apabila dibandingkan dengan nilai rerata pada siklus I. Peningkatan kemampuan membaca nyaring pada siklus II sebesar 12,59, kondisi awal 63 meningkat menjadi 75,59. Untuk lebih jelasnya lihat tabel berikut.

Tabel 1. Nilai Rerata Kemampuan Membaca Nyaring Siswa Pada Kondisi Awal, Siklus I, dan Siklus II

\begin{tabular}{cccc}
\hline \multirow{4}{*}{ Kelas } & \multicolumn{3}{c}{ Nilai Rerata } \\
\cline { 2 - 4 } II & Kondisi Awal & Siklus I & Siklus II \\
\hline
\end{tabular}

Peningkatan kemampuan membaca nyaring siswa kelas II SD Negeri Jabon 1 pada siklus II juga dapat dilihat pada diagram di bawah ini.

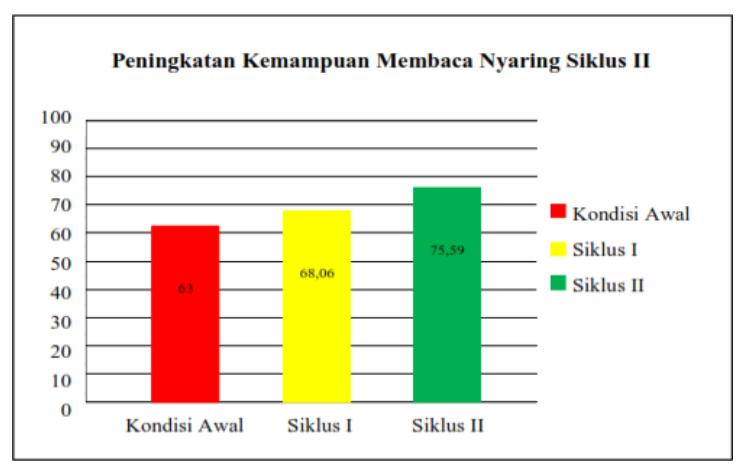

Gambar 1. Diagram Peningkatan Kemampuan Membaca Nyaring Siswa Pada Siklus I dan Siklus II 
Untuk mengetahui keberhasilan siswa dalam membaca nyaring pada siklus II dapat dilihat pada tabel berikut.

Tabel 2. Keberhasilan Siswa dalam Membaca Pada Siklus II

\begin{tabular}{rcccc}
\hline No & Angka & Kriteria & Jumlah Siswa & \% \\
\hline 1 & $80-100$ & Sangat baik & 15 & 75 \\
\hline 2 & $66-79$ & Baik & 4 & 20 \\
\hline 3 & $56-65$ & Cukup & 1 & 5 \\
\hline 4 & $40-55$ & Kurang & 0 & 0 \\
\hline
\end{tabular}

B. Pembahasan

1. Siklus I

Berdasarkan pengamatan yang dilakukan oleh peneliti, pada saat pembelajaran berlangsung sebagian besar siswa terlihat antusias. Namun, masih ada beberapa siswa yang terlihat tidak begitu antusias dalam mengikuti pembelajaran. Hal ini terlihat masih ada beberapa siswa yang ketika ada temannya membaca di depan kelas, siswa tersebut tidak menyimak dan memperhatikan temannya. Beberapa siswa ada yang jalan-jalan menghampiri temannya dan ada juga yang bercakap-cakap dengan temannya. Hal ini menyebabkan siswa yang tidak memperhatikan temannya yang sedang membaca tidak mengetahui letak-letak kesalahan dalam membaca nyaring yang dikoreksi dan dibenarkan oleh guru.

Guru juga kurang membimbing dan membenarkan jika ada siswa yang mengalami kesalahan dalam membaca nyaring. Guru kurang optimal dalam membimbing siswa-siswanya. Hal ini terlihat pada saat siswa membaca secara bergiliran di depan kelas. Terkadang guru tidak mengoreksi kesalahan-kesalahan siswa dalam membaca. Kedua hal tersebut menyebabkan kemampuan membaca nyaring siswa belum optimal.

\section{Siklus II}

Pada siklus II, proses pembelajaran membaca nyaring semakin meningkat apabila dibandingkan pada siklus I. Hal ini sesuai dengan pendapat Dwi Sunar Prasetyono (2008: 82) bahwa beberapa manfaat cerita bergambar yaitu menarik perhatian siswa dan menimbulkan motivasi atau merangsang siswa. Guru juga semakin intensif memberikan bimbingan kepada siswa dalam membaca nyaring.

Pada tindakan siklus II, 95\% dari jumlah siswa kelas II SD Negeri Jabon 1 yang mengikuti proses pembelajaran membaca dengan menggunakan media PPT Interaktif telah memperoleh nilai lebih besar atau sama dengan 65. Sebagian besar siswa memperoleh nilai kategori sangat baik yaitu pada rentang 80 - 100. Jadi, tindakan pada siklus II dinyatakan berhasil. Penggunaan media PPT Interaktif dapat meningkatkan pembelajaran membaca nyaring dengan baik. 
PTK, Vol.2 No.2 2022

ISSN: 2747-1977 (Print) / 2747-1969 (Online)

DOI: https://doi.org/10.53624/ptk.v2i2.51

\section{KESIMPULAN}

Berdasarkan hasil penelitian maka dapat ditarik kesimpulan bahwa terjadi peningkatan hasil belajar siswa di kelas II SD Negeri Jabon 1 Kecamatan Banyakan Kabupaten Kediri pada mata pelajaran Bahasa Indonesia melalui media PPT Interaktif dimana pada pra siklus ada 3 siswa atau $15 \%$ yang mencapai ketuntasan kemudian pada siklus I ada peningkatan yaitu ada 5 siswa atau $25 \%$ yang mencapai tuntas namun belum mencapai indikator keberhasilan sehingga dilanjutkan pada siklus II dimana ada 19 siswa atau 95\% yang mencapai tuntas. Dengan hasil demikian maka hasil penelitian sudah mencapai indikator yang ditentukan yaitu ketuntasan dengan KKM 75 sebanyak 95\% dari seluruh siswa yang dijadikan subyek dalam penelitian ini.

\section{DAFTAR PUSTAKA}

Aqib, Zainal. 2009. Penelitian Tindakan Kelas untuk Guru. Bandung: Yrama. Widya.

Dewi, Kurnia. 2017. "Pentingnya Media Pembelajaran Untuk Anak Usia Dini." Raudhatul Athfal 1.

Iskandar. 2009. Penelitian Tindakan Kelas. Ciputat: CP Pres.

Mulyanta and Marlon Leong. 2009. Tutorial Membangun Multimedia Interaktif Media Pembelajaran. Yogyakarta: Universitas Atma Jaya Yogyakarta.

Mustakim. 1994. Membina Kemampuan Bahasa. Jakarta: PT. Utama Graedia Pustaka Utama.

Nurgiyantoro, B. 2010. Penilaian Pembelajaran Bahasa. Yogyakarta: BPFE.

Qudsyi, Hazhira. 2010. "Optimalisasi Pendidikan Anak Usia Dini Melalui Pembelajaran Yang Berbasis Perkembangan Otak.” Buletin Psikologi 18(2). 